\title{
Pääsikö Venäjä lastenkodeistaan?
}

Vuodenvaihteessa 2014-2015 kollegani Maija Jäppisen kanssa esitimme Helsingin Sanomissa (27.12.2014) ja Idäntutkimuksessa (1/2015) kysymyksen uudesta lastenkodittomasta Venäjästä. Tällöin oli alullaan lastensuojelu-uudistus, joka globaalia lapsenoikeusperustaista deinstitutionalisaatio-ideologiaa mukaillen pyrkii purkamaan lasten laitoshoidon kehittämällä perheiden ennaltaehkäiseviä palveluja ja sijaisperhejärjestelmää. Reformia edeltävälle sosialistisen järjestelmän perua olleelle venäläiselle lastensuojelujärjestelmälle oli ominaista sijoittaa lapset suuriin, muusta yhteiskunnasta erillään oleviin lastenkoteihin sen sijaan että systeemi olisi tukenut perheitä. Kansainvälisessä vertailussa sijaishuollossa olevien lasten määrä ja sijaishuollon laitosvaltaisuus ovat Venäjällä korkeita. Tästä lähtötilanteesta ovat venäläinen sosiaali- ja perhepolitiikka sekä lastensuojelu olleet valtavien uudistusten ja haasteiden edessä. Onko Venäjä nyt sitten päässyt lastenkodeistaan?

Johtamassani Suomen Akatemian, Helsingin yliopiston ja Koneen Säätiön rahoittamassa kansainvälisessä monitieteisessä tutkimushankkeessa olemme tarkastelleet uudistusta erilaisin aineistoin ja menetelmin ja eri tasoilla tavoitteista toteutukseen. Uudistusta on ohjannut avainperiaate lapsen oikeudesta perheeseen. Tämä on tarkoittanut ennaltaehkäisyn osalta oikeutta jäädä biologiseen perheeseen, ja sijaishuollon osalta sijaisperhettä laitoksen sijaan ensisijaisena sijoituspaikkana. Kun oma biologinen perhe tai sijoitusperhe ei ole mahdollinen, voidaan lapsi edelleen sijoittaa laitokseen, joiden tulee olla mahdollisimman kodinomaisia eli pieniä laitoksia, joissa lapset elävät perheenomaisissa pienryhmissä.

Suhteessa aiempaan ideaaliin kollektiivisesta hoivasta suurissa lastensuojelulaitoksissa uusi ideaali kodinomaisesta perhehoivasta on merkittävä ideologinen muutos. Niin merkittävä, että näemme venäläisessä lastensuojelussa tapahtuneen paradigman muutoksen. Venäjä on vuosituhannen alusta saakka korostanut perhepolitiikkaa avaimena väestökriisin ratkaisemiseksi. Osana tätä perheitä korostavaa retoriikkaa ja satsauksia on lastensuojelu-uudistus ollut yksi valtakunnallisista prioriteeteista. Nykyisessä ylhäältä alas johdetussa järjestelmässä se on tarkoittanut sitä, että uudistus uusine ideaaleineen on rantautunut kaikkialle. Paine uudistaa sijaishuoltoa ja lastensuojelulaitoksia on ollut kova: esimerkiksi kuvernöörien tehokkuutta on mitattu perheisiin sijoitettujen lasten määrällä.

Paineen alla suunta on ollut periaatteessa hyvä. Sijaishuollossa olevien lasten määrä on laskenut hitaasti mutta tasaisesti. Sijoitusten paikan suhteen muutos on puolestaan dramaattinen. Lastenkoteja on lakkautettu ja remontoitu kodinomaisiksi. Niissä myös asuu entistä vähemmän lapsia. Siirtymä on tapahtunut nimenomaan sijaisperheisiin: jos laitoshoidon osuus oli 2000-luvun alussa 27 prosenttia ja sijaisperheiden yhden prosentin luokkaa, niin vuonna 2017 sijaisperheiden osuus oli noussut 28 prosenttiin ja vastaavasti laitoshoidon osuus laskenut kahdeksaan prosenttiin. Paradigman muutos politiikan ja tavoitteiden tasolla on siis johtanut myös tavoiteltuun institutionaaliseen muutokseen. 
Tutkimuksemme kuitenkin osoittaa, että vaikka muutos on todellinen niin ideologian kuin instituutioidenkin tasolla, se ei ole tapahtunut ongelmitta. Monenlaiset polkuriippuvuudet vanhasta järjestelmästä ovat hidastaneet käytänteiden todellista muutosta. Hoivan ideaalin ns. laadullisen muutoksen mittaaminen numeerisilla arvoilla, kuten perheisiin sijoitettujen lasten määrällä, lakkautettujen laitosten ja sijaishuollon piiriin tulevien lasten määrällä, on saanut aikaan odottamattomiakin seurauksia. Paine uudistaa on johtanut monenlaiseen numeroilla pelaamiseen ja institutionaalisen muutoksen imitointiin.

Periaatteessa lastenkoti-nimisiä (detski dom) lastensuojelulaitoksia ei Venäjällä enää pitäisi olla. Niiden seuraajissa, uusissa perhekeskuksissa, jotka vastaavat niin biologisten kuin sijaisperheiden parissa tehtävästä työstä ja nuorten jälkihuollosta, voi olla väliaikaisesti sijoitettuna lapsia ja nuoria. Käytännössä tämä muutos voi olla vain näennäinen: lastenkoti on muuttanut nimensä perhekeskukseksi, mutta lapset elävät pienryhmissä vain paperilla. Vanhojen rakennusten muuntaminen kodinomaisiksi ei riittämättömin resurssein ole aina helppoa. Erityisen huolestuttavaa on, että näihin perhekeskuksiin on syntynyt niin sanottu statuksettomien lasten joukko, joka saattaa elää laitoshoidossa epämääräisen ajan. Tämä seuraa siitä, että kun todisteena ennaltaehkäisevästä työstä sijaishuollon piiriin tulevien lasten lukumäärän tulisi olla mahdollisimman pieni, ei lapsia oteta virallisesti sijaishuollon piiriin. Tämä Venäjällä tarkoittaisi vanhempain oikeuksien menettämistä tai rajoittamista. Lapset saattavat ennaltaehkäisevänä toimena olla pitkään, ellei pysyvästi laitoshoidossa. Ilman virallista statusta heitä ei voida sijoittaa sijaisperheeseen. Näin heiltä vasten uudistuksen avainperiaatetta evätään oikeus sekä biologiseen että sijaisperheeseen.

Jos vanhat laitokset työllistivät kasvatus- ja hoivahenkilön lisäksi opetus- ja terveydenhoitohenkilökuntaa, niiden lakkauttaminen ei ole alueen työllisyyden kannalta hyvä. Väitämmekin, että tämän uuden laistohoidossa olevien lasten ryhmän syntyminen toimii osin laitosten olemassaolon oikeutuksena. Samoin kuin usein toistettu ajatus siitä, että "vaikeat lapset", kuten teini-ikäiset, isot sisarusparvet ja erityistarpeiset lapset, eivät sovellu sijaisperheisiin. Positiivinen uutinen onkin, että lähes poikkeuksetta pienet terveet lapset löytävät sijaiskodin. Käsittelemme laajalti uudistuksen toimeenpanon haasteita ensi vuonna ilmestyvässä hankkeen loppujulkaisussa Reforming Child Welfare in the Post-Soviet Space: Institutional Change in Russia (Routledge).

Edelleenkään Venäjä ei siis ole lastenkoditon, ja se tuskin olisi realistista, saati tarkoituksenmukaista. Pääasia olisi, että kukin lapsi yksilöllisessä elämäntilanteessaan saisi parhaan mahdollisen hoivan - tapahtui se sitten omassa biologisessa perheessä, sijaisperheessä tai laitoksessa. Voidaan todeta, että uudistus ei tapahdu ongelmitta, mutta suunta on oikea. Toistaiseksi kuitenkin edistysaskeleet tapahtuvat sijaishuollon puolella, kun oikea-aikainen ennaltaehkäisy on vielä lastenkengissä. Tässä, kuten koko uudistuksen alullepanijoina, venäläiset lastensuojelujärjestöt kulkevat etujoukoissa.

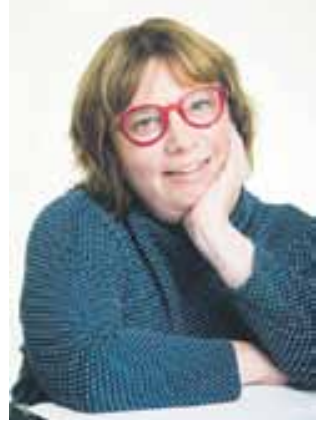

Meri Kulmala

Kirjoittaja työskentelee tutkijana ja tutkimuskoordinaattorina Helsingin yliopiston valtiotieteellisessä tiedekunnassa monitieteisessä yhteiskunnallisen eriarvoisuuden tutkimusaloitteessa (INEQ). 